\title{
o livro do Tinder (um match com Jac Leirner)
}

Pedro Ernesto Freitas Lima

O grande volume de cédulas de cruzeiro que se acumulava em gavetas devido a rápida perda de seu valor no período da hiperinflação brasileira nos anos de 1980 atiçou o interesse de Jac Leirner, que passou a colecioná-las. Nesse processo, a artista se deparou com uma série de grafismos e escritos realizados por anônimos nas cédulas, prática essa que transfigurava o estatuto do objeto: antes, algo que tinha valor de compra passava à condição de mero papel. O teor desses grafismos constitui a base para a elaboração de critérios classificatórios pela artista para produzir uma série de obras intitulada Os cem (1987-89). Dentre essas obras está O livro (dos cem) (1987), originalmente impresso em cartaz offset de dimensões $64,5 \times 55 \mathrm{~cm}$, na qual a artista apresenta uma compilação dos escritos encontrados nessas cédulas de cruzeiro. Em 1988, Leirner realiza outro "livro", Primeiros erros, integrante da série Erros (1987-1988), no qual, seguindo procedimento semelhante, coleciona jargões e anúncios publicitários. Nesses dois trabalhos, Leirner dá visibilidade para circuitos, juntamente com as informações que os mesmos veiculam, aos quais damos pouca ou nenhuma atenção. Essas duas obras são o ponto de partida para a elaboração da obra apresentada aqui. O livro do Tinder (um match com Jac Leirner) é uma daquelas obras que prestam homenagem. De forma análoga, busca dar visibilidade para o circuito, juntamente ao seu conteúdo, das descrições elaboradas em perfis do Tinder, aplicativo lançado em 2012 para plataformas móveis, cujo objetivo é promover encontros românticos entre pessoas, cruzando dados geográficos com preferências demonstradas na rede social Facebook. De forma breve, podemos dizer que $\mathrm{O}$ livro (dos cem) relata diversos tipos de desejos, principalmente amorosos e de riqueza, por parte dos autores anônimos, desejos esses que a publicidade parece prometer atender em seus enunciados, como observamos nos anúncios compilados em Primeiros erros. As mensagens encontradas no aplicativo Tinder também são da ordem do desejo, ora mais imediatos e pragmáticos, ora mais românticos e pretensamente líricos, de natureza kitsch, o que explica em parte a pertinência da escolha desse circuito para ser explorado. As descrições foram coletadas de perfis de usuários que foram apresentados ao autor desse trabalho pelo aplicativo, num raio de 109 km a partir do plano piloto da cidade de Brasília, a localização inicial do mesmo. 
vamo conversá gente bonita. Disponível para conhecer novas pessoas acima de tudo, o sexo vamos com moderação pq não sou puta. Forço a barra UMA vez apenas. Curto de tudo um pouco, adoro cara mais velhos que eu. Moro na Ceilândia. Foto? Mande primeiro, eu retribuo. Não tem muita coisa para dizer aqui não, só tem muito o que conversar. Dê o match aí e vamos conversar :p Brasília-DF, virginiano, 20 years old, estudante de engenharia civil. Cristão, Administrador, Goiano, a procura de uma princesa. Amizades são sempre vindas. É bom conhecer gente nova. Deus no comando. Cerimonialista. Servidor Público, Futuro Advogado. Apaixonado por barba, café, bom humor e pessoas tatuadas. Prazer. Sou mais do que os seus olhos podem ver... Pergunte e saberá! Min considero uma guerreira pois batalhou pelos meus sonhos todos os dias e não são poucos, pois tenho uma serena ambição e uma vontade de progredir enorme, tanto; que saí de meu país de origem atrás disso, então gostou muito de viajar e conhecer lugares e pessoas, a troca o aprendizado. Amo natureza, sou temente a Deus, de coração puro e valente para vida... Não me prendo a nada que me defina. Serei o que você quiser, mas só quando EU quiser. (Clarice Lispector). Gastronomo que possui como marca registrada a risada e amigos que a aturam. Estudante de Eng. Civil, sonho em conhecer o mundo em toda sua diversidade. Gosto de tudo um pouco e sempre quero conhecer mais. Engraçada, humorada, caseira, estudiosa. O silêncio, a calma e o simples me fascinam. Gosto de masculinidade: Aspecto e voz. Ausência de resposta, já é resposta. Não curto conversar com coisas inanimadas, membros inferiores ou superiores, gosto de conversa olho no olho, se não, não perca seu tempo. 23 anos, canceriano, administrador de empresas. "No final de tudo, seremos julgados pela coragem dos nossos corações.". Uma pessoa rasa é igual piscina com pouca água, não vale a pena nem mergulhar. A vida é feita do que vc realiza! Não Olho para passado, é o presente que me faz SER... CRESCER... VIVER! A princípio busco alguém bacana com personalidade pra conversar, trocar ideias, conhecer e ver o que rola. Aberto a possibilidades. Perfil do casal. Interessados em novas companhias para sair conosco, beber, ouvir boa música e nos conhecermos melhor. Basta apenas uma palavra e as palavras não bastam para me definir e jamais me resumir... eu sou muito e pouco... e sou tudo e nada... eu sou eu e eu apenas... Por fora o menino que muitos julgam... Por dentro o HOMEM que poucos conhecem!!! Casado com o Netflix, Amante do Spotify. Aquário com ascendente em peixes, seja lá o que isso queira dizer - we fake it, but we fake ir right. Sagitariano, Dj, calouro em Ciências Ambientais, apaixonado por animais, BSB-MG. Argentino em SP. Uma pessoa não deve ser julgada pelo seu corpo ou beleza e sim por seu sorriso e seus pensamentos. Ana Norte/DF, 23, projeto de advogado, solteiro, ariano, com ascendente em câncer, bonitin, vaidoso, sertanejeiro, romântico, ansioso, inquieto, curioso, animado, brincalhão, intenso, sincero até demais, carinhoso, impaciente e outras coisas mais. Hah ****atualmente platinado, mas por pouco tempo. Sinceridade acima de tudo!! Pisciano e poeta, so mais um comum. Garoto carioca, swing sangue bom. Carismático, Alegre, Espontâneo, Leonino, aventureiro, atleta, apaixonado pela natureza, romântico, solteiro. "Se eu não fosse modesto, eu diria que eu sou o melhor naquilo que faço...". De boa na vida. Procurando pessoas assim tbm. Cara decidido no que quer, ponderado nos ideais. Chama aê, vamo ver de qual eh e no que pode rolar. Cara a procura de uma boa conversa. Gosto de música, barzinho, jogo volei, a principio uma boa amizade. E e isso. Venha me conhecer e tire suas próprias conclusões... :D Sou um cara que já sei o que quero e amo a vida... tranquilo, amo a Deus, viajar, curtir os amigos, jogar vôlei, enfim, gosto de me divertir. Sou muito família e continuo acreditando que irei encontrar o pessoa da minha vida para compartilhar uma vida inteira juntos! Um ser especial de caráter que ama o belo. Com momentos de alegrias e tristeza. Busco o que me realiza. Até se for só pra conversar, já está ótimo! Nada a declarar... pois a vida e o que tem que ser, e forte é aquele que aguentar tudo o que ela fizer e ainda assim ser feliz. Permita-se. A vida não eh um clipe da taylor swift. A procura de novas experiências! Se dar bem com alguém! Conhecendo. Carioca, em uma sociedade surda e egoísta. O mundo é calmo aqui. "A vida é muito curta pra ser pequena". Sou um cara que admiro a vida acima de tudo!! Versátil! Solteiro, 1,85 alt, 74 kgs. Alguém de fato lê isso? kkk Whatever. 